

\title{
Construction, Validity and Reliability of Learning Style Inventory Dunn and Dunn (IGPDD)
}

\author{
Assoc. Prof. Dr. Mohammad Aziz Shah Mohamed Arip \\ Kalaiarasi Subarayan
}

Thenmalar Balasundram

Mohd Razin Abd. Rahman

Faculty of Education and Human Development, Sultan Idris Education University, 35900 Tanjong Malim, Perak, Malaysia

Email: aziz.shah@fppm.upsi.edu.my

\section{Doi:10.5901/ajis.2016.v5n3p35}

\section{Abstract}

\begin{abstract}
This study seeks to develop and acquire content validity and reliability of the Inventory of Dunn and Dunn Learning Styles (IGPDD). IGPDD questionnaire aimed to measure the learning styles of Form 2 students. Fundamental theoretical construction covers five aspects. IGPDD is produced by Model Dunn and Dunn Learning Styles. IGPDD contains 60 positive items which is divided into five sub-scale of the sub- scale 1: Environment (12 items), subscale 2: Emotions (12 items), subscale 3: Sociology (12 items), subscale 4: Physiology (12 items) subscale 5: Psychology (12 items). IGPDD content validity evaluated by nine experts comprising academics of lecturers from the Faculty of Guidance and Counseling, Sultan Idris Education University, Tanjung Malim, Perak, school counselors and school teachers . IGPDD gained high validity for overall which is 8.35 (83.5\%) and for sub scale of Environment (80.1\%), Emotion :8.16 (81.6\%), Sociology :7.91 (79.1\%), Physiology :8.55 (85.5\%) and Psychology $9.18(91.8 \%)$. Reliability analysis also showed high level of reliability which is .750, while subscale analysis showed moderate and low moderate where Environment subscale was .552, Emotion: .605, Sociology: .579, Physiology: .628 and Psychology: .625. By this result, it shows that this research was successful generate IGPDD questionnaire with good value of reliability and validity for use in schools. The findings are important to know the information related to the learning styles of the most sought after by every student in order to enhance the quality of learning and teaching process.
\end{abstract}

Keywords: Validity, Reliability, Dunn and Dunn Learning Styles Inventory.

\section{Introduction}

Every human being is born with a variety of skills and unique potential. Some of the skills, abilities and the potential grow throughout life through the process of learning and experience. Student responses on learning styles also vary depending on the personalities, the environment, classrooms, and teaching practices (Nor Junainah and Mohammad Aziz Shah, 2011). Students learn to read, see, feel, hear, and reflect, think logically and intuitively as well as memorizing, remembering, and reflecting by many different ways. Students will be learning when they are faced with conflict do not have the learning style that suits the character or personality of themselves. Consequently, students will become bored, cannot concentrate, fail to perform well in exams and raise the impact of the lack of interest towards the subject and cause them to give up (Baharin, 2000, Felder and Silverman, 1988, and Godleski, 1984).

Possessing learning styles can help a person to identify the learning environment and improve their learning performance (Dunn and Stevenson, 1997). Nor Rafidah, Hasnah, and Azielina (2012) it is important to adjust a student's learning style with teaching and learning situations. In Malaysia, teaching and lectures have become the norm and is most applicable in the study of schools and universities.

Dunn and Dunn learning styles is a module that is used to identify the preferred learning style of each student in the class. Model of Dunn and Dunn Learning Style states that a student has a learning style that depends on the elements that they like under five aspects of the environment (sound, light, temperature, and patterns), emotional (motivation, persistence, responsibility, and structure), sociology (self, spouse, friends, team, and teachers), physiology (perception, food, time, and movement) and psychological (global or analytic, left-brain or right brain, and impulsive or reflective) (Dunn and Burke, 2006).

In Malaysia, several studies have been conducted on learning styles. Asiah (1999) conducted a study in relation to 
a student's learning style and academic achievement among students of inventory flow technique using the Dunn and Dunn learning styles, and Prince (1978) showed that conclusive learning style is influenced by four stimulus factors consisting of environmental, emotional, sociological, physiological and psychological.

Previous studies found that, very little research has been done based on the study of the Dunn and Dunn Learning Style. Thus, this study should be setup based on module Dunn and Dunn Learning Styles. A mastery study skill for an individual is a very important aspect in order to achieve excellent results while adaptive learning style characteristics of an individual.

\section{Background of Learning Styles Dunn and Dunn}

Learning styles are important to a student so that it gives a positive effect on their academic achievement. Inventory of Dunn and Dunn Learning Styles (IPGDD) uses the term based on the concept of learning styles. Dunn and Dunn Learning Styles Model (1978) have been used in preparing these inventories and conducted research. According to Dunn and Dunn (1978), learning style can be defined as the way people began to focus attention, processing and recalling something new and difficult information. Dunn and Dunn (1978), refers to the learning style of the individual as a way to focus on understanding and recall of new information or skills. Prolonged studies (longitudinal) by Dunn and Dunn (1978) able to produce a model of learning styles and identify five categories of learning styles adopted by each individual. Therefore, an adjustment to the nature of individual learning styles and mastery of skills learned by an individual is very important to achieve good results.

Performance or achievements of a student depends on the role of a lecturer / teacher and the student's own role. Roles or responsibilities of teachers are not only as educators, but they also serve as mentors, managers, planners, administrators, and an evaluator. However, the achievement of a student depends mostly on the efforts taken by the students before the exam. Students themselves should strive to get excellent achievement or performance in examinations (Nor Rafidah, Hasnah, and Azielina, 2012).

Dunn and Dunn (1978) states that there is a difference or variation of an individual against the norms of the group, whether it is cognitive, emotional, physical, moral, behavioral, social, or talent in a group. This difference is related to aspects of identified physical, mental, emotional, and social. Consequently, there is a difference in the diversity of learning styles and preferences, learning strategies and different rate of learning for each student. There are individuals who have a dominant learning style, and there is also the use of different learning styles, which are adapted to the environment (Baharin, 2003).

Diversity of learning styles and need to be identified by the instructor prior to or during the process of learning and teaching so that teachers can prepare and make a thorough preparation with a view to the different backgrounds and knowledge of existing students.

\section{Literature Review}

According to Ibrahim and Assaadah (2011), Dunn and Dunn Learning Styles Model consist of four principles, namely Environmental Learning Styles, Emotional, Sociology, and Physical. This model emphasizes each individual has a particular learning style. Individual learning styles can also react with the climate, resources and approaches to teaching and learning.

Among the causes of the decline in academic achievement among students is that they failed to adapt to the way of teaching and learning in schools. In addition, they do not have a good learning style (Baharin, 2003). As a result, many students who fail to achieve excellent results themselves admit that the lack of knowledge in learning skills. They are difficult to find appropriate study skills for themselves. This suggests that the need for a student to know the learning styles and learning skills that is appropriate to themselves and their attitudes.

According to Mohd. Khairi, Suzana, and Sharifah Nurul (2011) findings showed that male and female students are stimulated by physical and environmental factors in their learning. Furthermore in terms of gender differences and learning styles and learning styles of boys show less auditory, kinesthetic, and tactile as compared to girls. Moreover, in terms of individual learning styles and visual, boys are higher than girls. In addition, to identify students' learning styles, two instruments of Learning Styles (Dunn and Dunn, and Price, 1978) and Perception Questionnaire Learning Style Selection (Reid, 1984) has been modified to suit the student.

Thus, according to Kamsani (2012), found that students who obtain high achievement in the subjects of Arabic Communication have mastered the auditory learning style better than the group that obtained low performance. However, 
the tendency of female students focused on visual learning styles, kinesthetic, analytical, and reflective. This indicates that their performance is better than the performance of boys.

Moreover, through the study of Meor Ibrahim and Assadah (2011) found a pattern of learning styles that are practiced by the respondents Year Two, Three and Four are not much difference. Respondents of Year Two were included in the active learning features, intuitive, visual, and organized while Year Three and Four of the respondents belong to their active learning features, concrete, visual, and organized.

Nor Rafidah, Hasnah, and Azielina (2012) conducted a study to determine the learning styles practiced by the students of second semester for Diploma in Accountancy, Diploma in Retail Management, Diploma in Marketing and a Diploma in Business Studies at the Department of Commerce, Polytechnic Sultan Azlan Shah, Perak, Malaysia. This study was conducted on 118 students of Diploma in Accountancy, Diploma in Retail Management, Diploma in Marketing and a Diploma in Business Studies at the Department of Commerce, Polytechnic Sultan Azlan Shah of Perak, Malaysia. The results showed that all second semester students in the Department of Commerce are more likely to adopt learning styles Active / Reflective Learners medium, Sensing / Intuitive medium Learners, Visual / Verbal Learners medium and Sequential / Global Learners medium.

Learning style has a significant impact on students' motivation. This can be seen through the study by Norlia, T.Subahan, Lilia and Kamisah (2006), which showed a significant relationship between learning styles and students' intrinsic motivation. According Baharin Abu (2003), the decline also occurred in academic achievement when students fail to adapt to the way of teaching and learning at the university and the students do not have the right learning style and fit themselves. As a result, many students who are less successful or failed to achieve excellent results recognize themselves as less knowledgeable about learning styles.

According to Kamaruddin, Roshidah, Mubin, and Nurul Azwa (2010) learning styles play an important role in improving student motivation. Thus, aspects of learning styles should be emphasized in education because these aspects have a significant impact on students' motivation. There are few studies that have been conducted within and outside the country in connection with Dunn and Dunn Learning Styles. There are many deficiencies in previous studies related to the Dunn and Dunn Learning Styles. Accordingly, this study was undertaken to determine the content validity and reliability to a detailed study to be carried out by the Malaysian environment and the lack of previous studies can be overcome.

\section{Basic Theoretical Construction of IGPDD}

Construction of IGPDD is based on the Dunn and Dunn Learning Style (1978) which classifies the learning styles of the five stimulus a) Environment, b) Emotional, c) sociological, d) Physical and e) Psychological and every part of this aspect own. Dunn and Dunn model was used to examine each student from kindergarten level up to the tertiary institutions. Listed are the five stimuli that affect the ability of an individual to the learning environment. Description of each sub-scale is as follows;

\subsection{Sub-scale 1: Stimulus Environment}

Environmental stimuli referred to the four elements, namely, sound, light, temperature, and patterns. According to studies by Dunn and Dunn (1978), there are individuals who need sound elements when studying for them, the sound of the radio or television will be able to make them become more concentrate in their studies. Light refers to the ratio of the appropriate light during the process of teaching and learning and the light that is needed by students to facilitate learning. The learning process is said to be more effective if it is carried out in a comfortable and air-conditioned since the hot temperatures will cause the mind and emotions of the students affected. Pattern or design of a study refers to the fit and comfort of a student to learn and it can reduce fatigue among students during school hours.

\subsection{Sub-scale 2: Emotional Stimuli}

Emotional stimuli are consisting of elements such as motivation, persistence, responsibility, and structure. Motivation is the driving force that drives a student to perform a success. In learning, incentives are given to motivate students in forms of grades, marks, prizes, or position in the class. Perseverance or tenacity is that a student pays full attention to help her learn for a long time. Pupils who are responsible will produce better quality work and have a more effective learning environment. How well emotions of a student can be identified by the structure or pattern of behavior in the process of teaching and learning. There are students who love to perform tasks in accordance with the directions of teachers and there are pupils who enjoy doing things on the initiative of themselves. 


\subsection{Sub-scale 3: Stimulus Sociology}

Stimulus sociology has elements such as you, pairs, in clusters, peers or adults. There are individuals who prefer to learn on their own and they do not want any interruptions when they learn like for example wasting time to talk with each other since it will cause them unable to focus on their studies. Another study of individuals in pairs eg, closest friends because they can communicate bilaterally when learning together. There are some individuals who make adults as their reference to ask questions when they are having difficulties in learning.

\subsection{Sub scale 4: Stimulus Physiology}

Physiological stimuli consisting of elements such as perception, food and drink, study time, and movement. Pupils who have a good auditory perception more willing to learn in a background full of noises such as music, radio, or cassette while students who are kinesthetic-tactile efficient and powerful, are more likely to learn by touching and feeling the presence of objects that are used. There are people who like to eat and drink while studying because when they eat or drink, the pressure can be reduced when learning. Appropriate study time have an impact on teaching and learning eg, morning and evening to create a fresh atmosphere, conducive, comfortable and more peaceful than studying in the evening. There are students who like to move around and change their seats if they are studying for a long time such as moving to get food, drink, or move to another place to continue learning and others (Dunn and Dunn, 1978).

\subsection{Sub-scale 5: Stimulus Psychology}

Psychological stimuli consisting of elements such as analytic / global, impulsive / reflective, and the left brain dominant / right brain dominant. Students who are perform analytical tasks are more careful and more focused doing every learning activity while global students see a picture with a more spacious and open-mindedness. Pupils who are possessed reflective learning style are the kind of students who love to learn to think, in other words using thinking skills to solve a problem. Left brain people have good thinking skills in the field of logic, quantitative, analytical, sequential language, facts, math, and memory, while the right brain people have good thinking skills in the areas of creativity, synthesis, color, design, feeling, rhythm, music, and imagination.

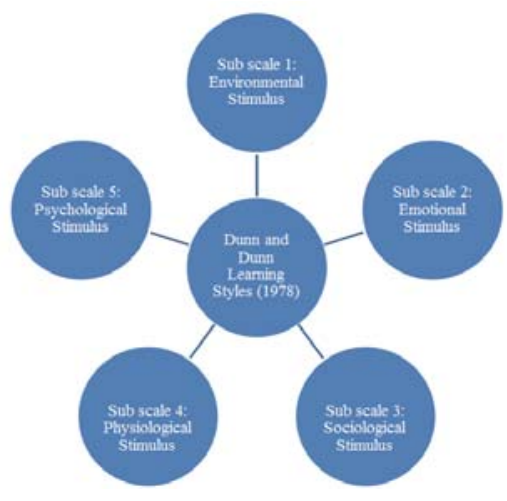

Figure 1: Basic Theoretical and Five Main Sub scale of IGPDD

\section{Construction, Scoring and Interpretation of IGPDD}

Dunn and Dunn Learning Style Inventory (IGPDD) capable of measuring the inventory elements of learning style that is owned by some learners in optimizing their learning. This IGPDD contains 60 items to measure five subscales which are; Natural (12 items), Emotions (12 items), Sociology (12 items), Physiology (12 items) and Psychology (12 items). Construction of IGPDD takes time between 15-20 minutes to answer it. The environment during answered this inventory should be conducive that is comfortable and does not interfere the subject. Respondents are required to answer it honestly. The answers form of IGDPP is in Likert scales that are in the form of choices between "YES" or "NO". 
Meanwhile, for scoring, IGPDD retort gives a value of 1 for "yes" and 0 for retort "NO". For the analysis and interpretation of the score, IGPDD suggest that respondents who score high between 41-60, are described as individual that are possessed higher learning abilities. However, for respondents who score between 21-40 and 1-20 shows that the individual regarding the stage has a low learning ability.

\section{Objectives of The Study}

This study aims to run:

a. Develop Dunn and Dunn Inventory Learning Style based on literature review.

b. Determining the value of the validity of the content of the main scale inquired about IGPDD.

c. Determining the validity of the content of the sub scale value inquired about IGPDD.

d. Determining the value of reliability IGPDD inquired about the major scale.

e. Determining the value of a sub-scale reliability inquired about IGPDD.

\section{Method of Study}

The form of this study is a descriptive study. The aim of descriptive study is to obtain the validity of the content and the value of reliability of IGPDD fostered through the study of literature. This study involves three-phase study that are; Phase 1: Development IGPDD, Phase 2: Getting the validity of content, and Phase 3: Analysis value of reliability.

\subsection{Phase 1: Development IGPDD}

Construction is done based on the literature studies and approaches the corresponding models. Based on IGPDD compliance with this, the approach chosen model is Model Dunn and Dunn Learning Style.

\subsection{Phase 2: Getting The Validity of The Content}

Once the items IGPDD has been fostered in phase one, IGPDD has been given to a panel of nine experts to be checked on the aspects of content accuracy. The panel comprises of four lecturers from Universiti Pendidikan Sultan Idris, Perak, Malaysia and five other people were submissive royal officials at the school as Professor, Senior Assistant Teacher, HEM Teacher, Co-curriculum Teacher, and Data Teacher. The checking was conducted by a panel of commensal aims to get value content of validity for IGPDD. The validity of which is done is important as a statement or explanation that is valid or true if it had accurately represent the characteristics of phenomena that is described, explained or theorized (Hammersley and Gomm, 1995).

\subsection{Phase 3: Analysis of Reliability}

The third phase was carried out aiming to get the reliability value of IGPDD. Reliability is related to measuring instruments that is used in the study to demonstrate how extent the findings of the research describe the world that is assessed in studies with consistent and right (Width Othman, 2011). After IGPDD get the reasonable value of the legal movement, IGPDD has been administered to 40 high school students in Perak, Malaysia. The sample selection is done by using simple random method. The data acquired were analyzed using SPSS to obtain the Cronbach alpha values for assessing the level of reliability of IGPDD.

\section{Results of Study}

Results of Phase 1: Development of scale, subscale and items inventory

Construction of IGPDD is based on the review of the literature on the models of learning styles. References are from the books, articles and several of journals inside and outside of the country. Based on this, IGPDD that is fostered contains 60 items which are divided to five sub-scale (12 positive items for each sub-scale): sub-scale 1: Nature (12 items), sub-scales 2: Emotion (12 items), sub-scales 3: Sociology (12 items), sub-scale 4: Physiology (12 items), and sub -scale 5: Psychology (12 items). IGPDD validity value is as Table 1 below; 
Table 1: The overall validity and sub-scales IGPDD $(n=5)$

\begin{tabular}{lccc}
\hline Scale/ Sub-scales & No. of item & Value (\%) & Expert Decision \\
\hline Overall IGPDD & 60 & $8.35(83.5)$ & Accepted \\
& & & \\
Nature & 12 & $8.01(80.1)$ & Accepted \\
Emotion & 12 & $8.16(81.6)$ & Accepted \\
Sociology & 12 & $7.91(79.1)$ & Accepted \\
Physiology & 12 & $8.55(85.5)$ & Accepted \\
Psychology & 12 & $9.18(91.8)$ & Accepted \\
\hline
\end{tabular}

Table 1 shows the overall validity of IGPDD is $8.35(83.5 \%)$. Based on the table, the highest content validity is 9.18 $(91.8 \%)$ of the sub-scale of Psychology, while the lowest content of validity is sub scale Sociology of 7.91 (79.1\%). For the other sub-scale for example Nature 8.01 (80.1\%), Emotion 8.16 (81.6\%) and Physiology 8.55 (85.5\%). This indicates that IGPDD items have higher content validity of experts.

Analysis of IGPDD reliability are shown in Table 2 below;

Table 2: The overall reliability and sub-scales of IGPDD $(n=60)$

\begin{tabular}{lcc}
\hline Test Reliability & Number of items & Cronbach Alpha \\
\hline Overall IGPDD & 60 & .750 \\
Nature & 12 & .552 \\
Emotion & 12 & .605 \\
Sociology & 12 & .579 \\
Physiology & 12 & .664 \\
Psychology & 12 & .628 \\
\hline
\end{tabular}

Table 2 shows the reliability analysis for IGPDD and it shows that the coefficient value of Cronbach Alpha is higher and satisfactory which is .750. This show IGPDD has good internal reliability and proven that IGPDD measure learning styles of the students. Based on the sub-scale, the overall reliability of IGPDD that is obtained the high reliability is the sub-scale of the Nature of .552,Emotion of 605 ., Sociology of $.579, .628$ Physiology and Psychology of .625. Meanwhile, the validity of the content IGPDD also has the high content validity. Thus, these findings indicate that the items in the inventory are good that the overall IGPDD is 750 .

Next, Table 3 below describes the reliability analysis to test the quality of the positive items built. Here's a list of items for inventory Dunn and Dunn Learning Styles (IGPDD); item sub-scale of 1-12 for the Nature, items 13-24 are Emotion subscales, items 25-36 are sub scale of Sociology, 37-48 items for Physiology and items 49-60 are sub scale of Psychology. Results obtained are as follows:

Table 3: Reliability Analysis of IGPDD according to items

\begin{tabular}{lc}
\hline Item & Alpha Cronbach \\
\hline I love learning with the melodious music. & .752 \\
I love learning with foot-tapping music. & .747 \\
I like to study in a quiet place. & .748 \\
I like to learn in a sunny place. & .750 \\
I always learn in a less luminous. & .756 \\
I love learning with study table lamp only. & .738 \\
I like to learn in the heat. & .741 \\
I like to learn in a place where the air is fresh & .748 \\
I like to study in a cold room. & .750 \\
I always learn to lie down on the bed. & .737 \\
I love to learn by sitting on the floor. & .743 \\
I always learn in a table and chairs. & .748 \\
I can stimulate myself to learn. & .749 \\
I need other people to stimulate myself to learn. & .748 \\
\hline
\end{tabular}




\begin{tabular}{|c|c|}
\hline I need a teacher to stimulate myself to learn. & .743 \\
\hline I always learn in a long time. & .732 \\
\hline I prefer to learn in a short period of time. & .761 \\
\hline I take a break before starting a new task. & .745 \\
\hline I have the responsibility to learn. & .752 \\
\hline I need a teacher to learn. & .743 \\
\hline I do not need help from others to complete a task. & .741 \\
\hline I love to learn by class schedules at school. & .739 \\
\hline I like to study during breaks only. & .748 \\
\hline I like to learn by providing a timetable at home. & .738 \\
\hline I learn better if learning itself. & .752 \\
\hline I love to learn in pairs. & .742 \\
\hline I love to learn with their peers. & .743 \\
\hline I like to learn in a large group. (more than 5 persons) & .736 \\
\hline I like to study in small groups. (5 persons) & .749 \\
\hline I love learning with the teacher next door. & .733 \\
\hline I feel good if learning by doing experiments in class. & .748 \\
\hline I love learning with the teacher next lift. & .734 \\
\hline I would understand if learned while talking with friends. & .752 \\
\hline Learn in pairs can improve knowledge on a particular subject. & .746 \\
\hline $\begin{array}{l}\text { Learn with the juxtaposition of teachers found it can improve } \\
\text { morale and belief. }\end{array}$ & .739 \\
\hline I prefer to remember things by studying alone. & .759 \\
\hline I would understand if learning with concrete objects. & .744 \\
\hline I love to learn to use computers. & .743 \\
\hline I love to learn that there is a picture chart. & .746 \\
\hline I love to eat junk food while studying. & .749 \\
\hline I always drink while studying. & .748 \\
\hline I like to chew gum while studying. & .742 \\
\hline I like to study at midnight. & .754 \\
\hline I like to learn in the morning. & .740 \\
\hline I like to study in the evening. & .733 \\
\hline I like to read while traveling. & .736 \\
\hline I love learning while standing. & .735 \\
\hline I always change seats during the study. & .756 \\
\hline I prefer to learn when to study drawing mind maps. & .762 \\
\hline $\begin{array}{l}\text { I have a better understanding of learning by listening to teacher } \\
\text { explanations. }\end{array}$ & .759 \\
\hline I prefer to study subjects of language. & .751 \\
\hline I prefer subjects based on the calculations. & .748 \\
\hline I learned over time when I can create a model. & .750 \\
\hline I enjoy learning when to do practical work. & .745 \\
\hline I learned over time when I make something for a class project. & .756 \\
\hline I love Science subjects. & .753 \\
\hline I love Mathematics. & .748 \\
\hline I love Bahasa Malaysia. & .749 \\
\hline I love Art Education subjects. & .747 \\
\hline I love the subject of Music. & .753 \\
\hline
\end{tabular}
Note: all items are positive.

Based on Table 3 above, the lower reliability is .732 for item no.16 under the sub-scale of emotions. Meanwhile, the highest reliability is .762 of item no. 49 under the sub-scale of Psychology. The high reliability for each item indicates the quality of the item being built is at a good level, satisfying and can be understood by the respondents. This is consistent with the opinion submitted by Mohd Majid (1998) which states that the coefficient of reliability of 0.60 or more is good and acceptable. 


\section{Discussion}

This study able to contribute significantly to the educators to recognize the appropriate learning style among students in their respective schools. Furthermore, there is still no standardized inventory that can be used as a benchmark measure of all schools in Malaysia to measure learning styles are most interested by students in school. Thus, it is hoped that the construction of IGPDD has significant contributions to educators in order to improve the level and quality of teaching and learning in the classroom.

Based on the analysis conducted, the whole and overall of reliability and validity of IGPDD is high. Results that are obtained from this pilot study clearly shows that IGPDD able to explain about the learning styles of the most sought after by students which is represented by the five major sub-scale environmental, emotional, sociological, physiological and psychological.

Based on the findings of the validity and reliability of IGPDD obtained is high, researchers suggest that this IGPDD could be used and implemented in a more comprehensive and widespread especially in high school or even elementary school. In addition, it is proposed that further research should be conducted to make a more in-depth statistical analysis of the items in IGPDD and make improvements to the built of the items. The aim of the improvement is to produce a higher quality version of IGPDD in the future. Thus, it is proposed that items for these subscales should be restored and improved to get the good content of validity.

For the design of such studies in the future, some of the following considerations are suggested. Future studies should use more than one class to demonstrate the higher validity and reliability. In addition, the construction of the items needs to be more aware of the concept of learning styles in the future. This should be taken into an account when to improve the model studies or inventories to produce more robust findings.

In addition, all planning to create excellence students in physical, emotional, spiritual, intellectual, and personality should be taken seriously. Society nowadays expects future generations to excel in various aspects and practice of lifelong learning. But the reality of students now studying only for the exam alone and the achievement of secondary school students in urban and rural areas are different. The effect is on technology, research and the economy will be far behind compared to developed countries. Therefore, all parties should act with sound and fast especially those who involved in the education system, such as the Ministry of Education, schools, and teachers.

Therefore, the school should be changed in order to improve the level of formal school culture to a higher level and make an effort to keep it. Similarly, the aspects of teaching and learning should be emphasized. Teaching and learning will be more effective if teachers were able to identify students' learning styles.

\section{Conclusion}

Overall, this study successfully built Inventories Dunn and Dunn Learning Styles with the content validity and high reliability and satisfactory. So, this IGPDD is able to assist in the teachers to know about learning styles that is preferred by their students and can customize the style of teaching and learning in their students' tastes. Analysis of each item appearing in IGPDD also has the high reliability which shows that IGPDD can identify students' learning styles.

\section{References}

Asiah Haji Parriekutty (1999). Gaya Pembelajaran dan Pencapaian Akademik di Kalangan Pelajar-pelajar Tingkatan Empat Sekolah Menengah Teknik Juaseh, Kuala Pilah, Negeri Sembilan Darul Khusus. Universiti Malaysia.

Baharin Abu (2003). Teaching Effectiveness and Staff Professional Development Programmes in Hei in Malaysia. Unpublished Doctoral Thesis, University of Birmingham, UK.

Bell, M. E. (1972). Learning and Instruction: Theory Into Practice. New York: Macmillan Publishing Company.

Zanariah \& Bhasah (2009). Satu Pemerhatian Terhadap Gaya Pembelajaran Murid Sekolah Rendah dan Menengah Di Lembah Kelang. [May 29, 2014] Available: http://bhasahabubakar.blogspot.com/.

Dunn, R., \& Burke, K.. (2006). Learning Style: The Clue To You. [July 7, 2014] Available: file:///C:/Users/USER/Downloads/lssy_ rimanual_v1\%20(1).pdf.

Dunn, R. \& Dün, K. (1978). Teaching Students Through Their Individual Learning Style:APractical Approach. Virginia: Reston Publishing.

Eva Cheong, S. C. Chong \& H. N. Ling. (2012). Gaya Pembelajaran. [May 29, 2014] Available: http://dpliprasekolahsunshine. blogspot.com.

Garger. S \& Guild, P (1984). Learning Style: The Crucial Differences. Curiculum Revies, 1 (23), 9-12.

Hammersley, M. \& Gomm, R. (1995). Bias In Social Research. London: Routledge. 
Heynes, M. E. (1989). Make Every Minute Count, How to Manage Your Time Effectively. London: Crisp Publication.

Kamaruddin Illias, Roshidah Abdul Rahman. Mubin Md Noor \& Nurul Azwa Saison (2010). Pengaruh Pembelajaran Terhadap Motivasi dan Pencapaian Akademik Pelajar Pra ljazah Sarjana Muda Perguruan Institut Pendidikan Guru Kampus Ipoh. Jurnal Penyelidikan Dedikasi, 2, 141-153.

Kamsani (2012). Hubungan Gaya Pembelajaran Dengan Pencapaian Pelajar Dalam Mata Pelajaran Bahasa Arab Komunikasi Di Maktab Mahmud, Alor Setar, Kedah. Tesis Sarjana Sastera. Universiti Utara Malaysia.

Kamus Dewan (2005). Edisi ke-4. Kuala Lumpur : Dewan Bahasa dan Pustaka.

Mak Song Sang (2008). Ilmu Pendidikan Untuk KPLI Sekolah Rendah: Psikologi Pendidikan dan Pedagogi. Selangor: Kumpulan Budiman Sdn.Bhd.

Meor Ibrahim \& Assadah Mohamad (2011). Kajian gaya pembelajaran dalam kalangan pelajar UTM. Journal of Educational Psychology and Counseling, 2, 51-77.

Nor Junainah Mohd Isa \& Mohammad Aziz Shah Mohamed Arip (2011). Pengenalan

Pembangunan Sahsiah. Bab 7 Pendekatan Pembelajaran: Teori (Page: 116 - 128). Emeritus Publication.

Mohd. Majid Konting (1998)."Kaedah Penyelidikan Pendidikan". Kuala Lumpur, DBP

Mohd. Khairi, Suzana, Nurul \& Sharifah (2011). Amalan gaya pembelajaran dalam peningkatan prestasi akademik di kalangan pelajar jurusan perakaunan kolej matrikulasi melaka. Jurnal Pendidikan.

Norlia Abd Azia, T. Subahan, M. Meerah, Lilia Halim \& Kamisah Osman (2006). Hubungan antara Motivasi, Gaya Pembelajaran Dengan Pencapaian Matematik Tambahan Pelajar Tingkatan Empat. Jurnal Pendidikan, 31, 123-141.

Nor Rafidah Binti Abdul Rahman, Hasnah Binti Ngah, \& Azielina Binti Mohd (2012). Pola Gaya Pembelajaran Pelajar DAT, DPR, DPM dan DRM Semester Dua, Jabatan Perdagangan, Politeknik Sultan Azlan Shah. Penyelidikan dan Inovasi Memperkasa Kualiti Pendidikan. TVET, 78-88.

Othman Lebar (2011). Kajian Tindakan Dalam Pendidikan-Teori dan Amalan. Edisi Pertama. Perak, Malaysia, Universiti Pendidikan Sultan Idris.

PdP Ke Arah Pembelajaran Masteri. [May 24, 2014] Available: www.teachersrock.net/masteri3.htm. 
